\title{
IDS RESEARCH
}

\section{Conflict and Clientelism in a Bihar Village}

\section{by Geoff Wood}

Any explanation of the depressing rural scene in India cannot be found solely in the village; it must be sought also in the wider economic and political environment. A study which starts at village level has the value of describing some of its essential features and of proposing hypotheses about changes which might occur within the village in response to alternative external conditions. The next step is to examine these hypotheses in the context of the broader environment in Pachera village in Purnea District. The present discussion summarises the impact of recent policies and legislation, and examines (pessimistically) the prospect for revolution in Northeast India and the probable cost to the peasant of such an outcome.

\section{Recent Policies and Legislation}

Tenancy legislation, Community Development, Intensive Agricultural Area Programmes (IAAP) and projects linked with IAAP (irrigation and the Small Farmers Development Agency in particular) have all contributed to the formation of contemporary economic and political organization in the village.

The most significant piece of tenancy legislation has been the abolition of Zamindari in 1951; under this legislation, those who collected rents from tenants and paid a proportion of it in revenue to the Government (1/10th in the 1940's) surrendered this right, which had been granted to them under the terms of the Permanent Settlement in 1873. All this land was vested in the state, and the raiyat (tenant-cultivator) paid revenue direct to the Government. The Survey and Settlement Operations from 1953-58 ensured that a raiyat's holding was recorded, and could henceforth be sold, mortgaged or inherited by that raiyat's descend-

* Geoff Wood is a Research officer at the IDS. 
ants. Ex-Zamindars were allowed to retain rights to land which they were personally cultivating, although ceilings on the amount of land that could be registered under one person's name were formally imposed in 1962. Purnea itself acquired notoriety on account of the 60,000 title suits arising from the Survey and Settlement Operations, of which 25,000 had been disposed of by 1971 .

In Pachera village, the ex-Zamindar, Sashi Mohan Jha, personally cultivated 350 acres, and a further 150 acres of his was sharecropped by the inhabitants of the village. At the time of the survey the richer peasants in the village persuaded the ex-Zamindar to sell this land to them after hindering his cultivation. By 1971 only 25 acres were still in his possession, and this was leased out to sharecroppers. Another smaller type of Zamindar, Jahrul Hassan, had rights over 250 acres in the area (including a part of Pachera), which were managed by a Khangar (scheduled caste) patwari , who is now one of the two richest farmers in the dominant peasant group in the village as well as its informal Mrikhiya (headman). Sashi Mohan Jha's Zamindari was managed by the Muslim descendants of Jity Patwari who worked for Sashi Mohan Jha's grandfather and who had established the Muslim community in Pachera. At the time this land was released on to the market, the leading members of this Muslim lineage together with the betteroff of the Khangar peasants purchased land of good quality in greater amounts than anyone else in the village, thereby maintaining or even enhancing their economic and political strength in the village.

Subsequent legislation of significance to Pachera was the Bihar Tenancy (Second Amendment) Act of 1955. This was designed to provide greater protection for sharecroppers by restricting kind payments to $7 / 20$ ths of the produce of the land, excluding any share in straw, jute sticks, etc. The systein of realising a fixed rent in kind was prohibited. Provision was made to restore possession to those sharecroppers who had been ejected by their landlords illegally after January 1953. The Bihar Land Reforms (Fixation of Ceiling Area and Acquisition of Surplus Land) Act, 1962, included provision for registering sharecroppers as raiyats, but this has not been implemented because of 1 aw and order risks arising from the landlords' probable reaction.

The most obvious effect of these pieces of legislation has been to reduce the extent of sharecropping through land purchases and to stop the outflow of exorbitant payments in rent to an outsider who did not reinvest any part of them in the village, thus

Keeper of records. 
a greater control by cultivators over the distribution of their produce. It is fair to assume that the amount of marketed surplus was affected by Zamindari abolition, and that the cultivator and his family began to consume some of the output previous ly appropriated in rent. Payment in kind has not increased and cash wages have only in the last 2 years increased (in some cases by 12\%); after other normal expenditures (debt repayments, marriages etc.) any remaining surplus was at first deployed in the acquisition of 1 and. As a result, the Khangars and Muslims have become the dominant landholding groups in the village, followed by the Bais Banias. These groups however, are far from homogeneous. Two Khangar and two Muslim families are dominant, and three of those families had previously been connected with the management of the $Z$ amindaris. The two joint Khangar families own 80 and 60 acres, respectively, and each now owns a tractor. A further ten Khangar households own between 10 and 20 acres, and a large group own between 5 and 10 acres. At the lower end of the scale, there are some very poor Khangar families with small, infra-subsistence holdings, supplemented by share cropping arrangements and some wage labour. This pattern is repeated in the Muslim and Bais Bania castes, although a smaller proportion of their households are in the 10-20 acre category. The Khangars consist of 55 households, the Muslims of 52, and the Bais Bania of 24. These figures need to be set against the 81 households of the Mushar caste - which consists mainly of landless labourers. This group is relatively new to the village. Members of some households who immigrated here during the period of expanding land acquisition by the peasants, recall that employment opportunities were greater than in their previous home further to the West of the District. The older Mushar families used to work for the Zamindar and for the Zamindar's sharecroppers.

The Community Development Programme began to function in 1952, aided by a plethora of egalitarian propaganda on the radios and in the newspapers. Its essential shortcoming appears to have lain in the attempt to democratise the village without altering property relationships. The introduction of village councils, based on the Gandhian notion of independent village republics ignored the effects of petty tyrannies of the past, which thus were institutionalised and found convenient protection for the future in rational ideology and bureaucracy.

Pachera village lies in the Panchayat of Kamalpur, which includes 7 other villages and has a total population of 11,967 in 1971, whereas Pachera is 1,612. The elected Mukhiya (headman) of the Panchayat is Jahrul Hassan from Rampur village, who has 
had a small Zamindari in Pachera and elsewhere in the Panchayat. He was the first Mukhiya, elected in 1955; on that occasion his opponent received only a handful of votes, and, he has been unopposed ever since. The Sarpanch (judge) used to be his patwari from Pachera - the rich Khangar and informal Mukhiya - until his age compelled him to nominate a successor.

During this time, not one dispute requiring judgement has been forwarded from Pachera to the Panchayat. Disputes in ' Pachera are either settled by the leaders of each caste hamlet (tola), or if judgements here are not accepted, or another tola is involved, or wider implications for the village are perceived - then the leading Khangar and Muslim families obtain the relevant facts and make a judgement. The ex-Sarpanch and informal Mukiya pronounces judgement and sentences (usually a fine). Those sitting in judgement are the richest landholders, contro1ling the majority of the labour force directly or, in the case of middle and poor peasants, indirectly through their moneylending and trade activities such as shops. Parties to the dispute invariably request these leaders to sit in judgement, thus reinforcing their power in the village. Judgement by anyone else could not enjoy any legitimacy in the community, and would be unenforceable. Some cases have been taken to the courts, but most of those were eventually withdrawn and settled by negotiation within the village.

One of the aims of Community Development is that changes should occur democratically through a process in which all the villagers participate and express their needs. The Mukhiya and his council would have resources at their disposal to meet some of those 'felt needs'. The only evidence of Panchayat initiative since 1955 is provided by two hand tube-wells, sunk in Pachera. The only activity which frequently demands the Mukhiya's intervention is the organisation of relief. The distribution of grain is carried out by him on behalf of the Block Development Office (B.D.O.), and requires, in principle, little discretion. But by distributing to the disabled rather than the starving the Mukhiya succeeded in undermining the incipient leadership of a Yadav* dissident, who persists in encouraging landless labourers to seek higher wages and to get land registered in their names. The denial of grain hand-outs to his followers took away his credibility overnight. The other case involving relief in Pachera also concerned the Mukhiya. A contractor from Kamalpur village persuaded the Mukhiya to support a scheme of manual work for the labourers, which would be met out of the relief

Yadav is the name of a caste. 
funds at the Block Office. The labourers should have received Rs. 21 per 1,000 cu. ft. of earth shifted; instead they received Rs. 13, and the contractor (and who else?) received the difference.

The second theme in Community Development is the assumption that India's peasants will want economic progress and sustain it through their own efforts once its advantages have been shown to them. This requires an extension service by which fresh resources and new ideas are brought to the village through the bureaucracy, their efficacy is explained and demonstrated, and the peasant thereafter left to adopt them. Neither the village social structure nor the wider political and economic environment within which villagers have to make decisions are regarded as influencing these processes either negatively or positively, or as being in need of change.

This doctrine has persisted through the introduction of the IAAP, which now covers the Western part of Purnea District, and included Pachera village. In Purnea this programme operates in conjunction with the introduction of canal irrigation in the mid-60's. The advent of new technology and more crop varieties represents a marginal rather than complete change of behaviour, and applies in varying degrees to different cultivators. The main change in Pachera has been through the introduction of exotic varieties of wheat - high yielding and improved - which require the controlled water supply provided by irrigation. The gross cropped area in Pachera went up from 595.4 acres in 1961 to 1,200 in 1971, of which 1051.66 acres were irrigable. Irrigation was first available in some parts of the area in 1965. In the 1966-67 season, there were 65 acres under Lerma Rojo*; in 1967-68, 120 acres were under high yielding varieties; rising to 143 acres in 1968-69. By 1971-72, this area had increased to 200 acres, with 5308 (a variety of wheat) representing 60 per cent of the crop. High yielding varieties of paddy have rarely exceeded 3 per cent of the total cropped paddy area.

The principal method by which innovations are induced in the village is through the village worker (VLW), whose functions have now been restricted to agricultural extension. In Pachera, he lives with the informal Mukhiya and tends to work only with the richer Khangar and Muslim families. His behaviour is as much determined by the political structure of the village as is that of any other inhabitant. Smaller

A high-yielding, Mexican variety of wheat. 
peasants and sharecroppers rarely see him, let alone talk to him. The VLW is also responsible for the other villages in the Panchayat, and he spends a great deal of his time filling in crop records and collecting statistics for the Block office. $\mathrm{He}$ is responsible for obtaining block credit for goods and fertilisers, but tends to do this only for the richer peasants. The other institutional source of credit is the multi-purpose Cooperative Society, whose secretary is the head of the other rich Khangar household, who tends to inform only his close friends of the arrival of seeds and fertiliser. Others have to find out for themselves, and many of the small farmers (2.5-5 acres) are unaware that they are entitled to more favourable credit facilities, or indeed that they have been taken into the Small Farmers Development Scheme at all. The principal source of private credit in the village is the rich Khangar who is the VLW's host.

Thus we see how the successful introduction of the new technology depends upon existing political and economic relationships between rich and poor in the village, and how access to the opportunities provided by the new technology is therefore restricted. At the same time wheat growing has certainly increased steadily in the village as a whole, but only the richest households boast an output which exceeds their consumption requirements. And even this surplus is insignificant and irregular. The major source of cash is the growing of jute which, apart from the adoption of some spraying, has been largely unaffected by these developments. But again, with the exception of the richest families, cash derived in this way is spent on the normal consumption requirements of the household meat, vegetables, oil, kerosene, debt repayment (when not in kind), clothes, marriages, etc. Surplus from jute in excess of these requirements, together with a surplus from paddy and wheat, is only enjoyed regularly by the 4 or 5 richest families. In this way they have been able to acquire extra land at a faster rate; 2 have been able to buy tractors; pucca houses are built, shops and a mill acquired, trading activities financed, money loaned and children are sent away to schools and colleges. As land becomes scarcer, sharecropping becomes a precarious, short-term arrangement, increasingly subject to sudden termination. Labour is plentiful, and its price is therefore kept to a minimum subsistence level. The small peasant survives, partly because this price for labour cannot go below subsistence level, but he cannot accumulate. With the scarcity of 1 and, the middle and richer peasants can only turn to a more intensive cultivation of their plots and, where they obtain surpluses, 
either invest in their cultivation or diversify into other activities. This process reinforces the political structure which in turn sustains it.

Apart from the increasing inequalities which thus arise in the village, the implications of this process are more widespread. If the existing policies continue to be applied, and in the way described, the essential problem of extracting a surplus for general economic growth both in the towns and the countryside will remain. This was one of the consequences of the 'New Economic Policy' (NEP) in Soviet Russia, with a strong inclination by the richer peasants to sell their produce locally and engage in commercial activities of ten in the local town. As traditional ties dissolve into wage labour, the landiess labourers lose their previous economic security and physical protection, and increasingly ressemble a rural proletariat. As these advantages of being a traditional rural worker disappear, the exodus to urban slums hastens. The catchment area of Calcutta includes Purnea. The following section examines whether this process of proletarianization could generate any process ressembling radical upheaval in the countryside.

\section{The Prospect for Revolution}

The most obvious source of potential insurrection in Purnea and indeed elsewhere in the plains of Bihar, Bengal and Uttar Pradesh is the large emerging rural proletariat of landless labourers. It has become increasingly disengaged from those traditional structural relationships which allocated some status and security in the village social structure, and at the same time increasingly dependent on daily wage labour, which is a highly insecure source of income in the present situation of labour abundance. The revolutions of Russia and China were conducted largely without the involvement of a rural proletariat. The evidence from Purnea is a little ambiguous. In Pachera village the main group of landless labourers are Mushars - living in 3 separate tolas. One tola is the 'territory' of the Khangars, another the 'territory' of the Muslim peasants, and the third divided up among Khangars, Muslims and other peasant castes. They complain bitterly that they are given no opportunity, and that they are robbed ( $c f$. the case, of the relief earthworks). An attempt to seek higher wages fizzled out with no unity among the three tolas, although the richest families conceded a 12 per cent cash increase (with kind payments unchanged) apparently to secure and maintain the loyalty of 
their respective 'territory'. At the same time Mushar leaders understandably seek every opportunity for personal gain. Interest on loans within the caste are as exorbitant as those granted by other castes; they will take work on contract and hire fellow caste men at basic rates and work them hard; and in the case of the earth-works, for example, the Mushor leaders were bribed and paraded before the block officials when the wage rate was challenged. Although a Socialist Yadav works among them, he despairs at the response - they are not agressive about seeking employment or land. This might be expected, but their behaviour contrasts dramatically with those of the Santhals (a scheduled tribe group in the village, originally from South Bihar). The kinship and political links of the Santhals are more widespread geographically, information and success stories pass quickly. They constantly hustle for land and employment - going outside the village which the Mushars would never do. They try to sharecrop, and rear buffaloes for dairy purposes, but also for ploughing on their own or another's land. A recent incident in Rupeshpur in Dhamdaha block to the Southwest of Pachera ended in the death of 14 Santhals - burnt and shot by the dominant peasant group. This was the result of a long dispute over rights to land and sharecropping. Within 2 days, a meeting of 7,000 Santhals had gathered demanding vengeance.

One cannot simply attribute the difference between the Mushars' behaviour and that of the Santhals to a variation in the kinship and social structure of their respective communities. The Santhals were brought to the western part of Purnea at the turn of the century to clear the jungle by the Bhumihar Brahmin and Rajput landowners who had migrated there because of the low land rents at that time. The Santhals have long resented these large landowners who have acquired wealth by exploiting them. The sense of polarisation in this area is very strong, which explains why the Naxalites from Calcutta and Delhi chose to work there. Before they were rounded up in the middle of 1971 , it appears that they made little impact with any of the other landless labourer groups or small peasants. Those peasants I spoke to were very hostile to the Naxalites, although respectful rather than cynical about the self-sacrifice of the St. Stephen's College boys.

It appears from the foregoing comparison between the Mushars and Santhals that the history of polarisation in Dhamdaha was the significant variable. I know of another village 20 miles south of Pachera where more than 50 per cent of the households are landless labourers, and where there exist some 
very rich farmers, two of them owning 350 acres and 400 acres, respectively. Here there has been a recent involved history of labour strikes and land disputes, with battles in the fields. The leaders have been scheduled caste Hindus - Tatmas and yadavs. There are more conflicts to come, but the large farmers have been sufficiently threatened and scared to recruit local officials and magistrates to their cause, and even to persuade a local leader of the Communist Party to tell the militants to reduce their activities. If polarisation is a significant variable in landless labour militancy then implementation of existing ceiling legislation and small farmers schemes to preserve the smaller holdings will function to disperse the hatred of the absolute have-nots. The high number of small and middle peasants in Pachera and the absence of militancy among the numerically dominant Uushars might be thus explained.

If this is so, then the expectation of a natural alliance between urban proletariat and poor peasants and landless labourers as a result of close division in the village must be queried. Certainly peasants only participated actively in the Bolshevik revolution in the first phase of the seizure of power, and subsequently after the brief period of NEP - the leadership turned on the peasants, driving those who had brought them to power into collectives in order to make them the main basis and victims of primitive socialist accumulation. This experience may make us feel that urban leaders have little to offer the small peasant, but they also have little opportunity of prising the landless labourer apart from his community as long as prevailing policies continue to diffuse class antagonisms and exploit existing rural political structures in doing so, with close economic and social dependence of the poor on the rich.

On the other hand without urban leadership it is doubtful whether anything could happen. The Chinese communist leaders made little headway until the late $20^{\prime} \mathrm{s}$, and indeed were severely compromised and almost destroyed by the Kuomintang as long as they stuck rigidly to the Marxist doctrine of the importance of the urban, industrial proletariat as the vanguard of revolution. It was only when they joined with the peasant against the bourgeois and then occured the feudal reaction of the Kuomintang that some exchange between peasant and urban proletariat could occur with advantages to both. Neither component could have succeeded independently, yet the success of a peasant revolution ultimately depended upon the organisational ability of the urban revolutionaries, despite their 
awareness that there would have to be subsequent expulsions of the richer peasants and petty landlords as the revolution advanced towards socialism.

Naxalites activity is the example of this approach in West Bengal and Bihar, but to be successful in the countryside demands a higher level of organisation and discipline in the cities than at present prevails. Meanwhile if the current policy of aid to the middle and smaller peasants (2.5-5 acre holdings) through IAAP, small farmers schemes and imposition of land ceilings continues and succeeds, then the prospect indeed looks gloomy for those small peasants in areas not yet involved in privileged extension relationships; as it does for sharecroppers who are excluded from the benefits of these schemes, and the landless agricultural labourers - not to mention the urban proletariat. Meanwhile the alliance of $\mathrm{rich}$ and middle peasants with the urban bourgeoise, the administration, the military, the police and the large industrial capitalist families - the alliance, that is, which pays tributes to the peasant populist parties - appears strong enough to ensure their security for some time to come. 